\title{
Clinical Evaluation with Self-sequential Longitudinal Reference Intervals: Pregnancy Outcome and Neonatal Thyroid Stimulating Hormone Level Associated with Maternal Thyroid Diseases
}

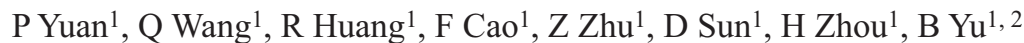

\begin{abstract}
Objective: We attempted to evaluate maternal thyroid function in a new self-sequential longitudinal reference interval (SLRI) which we established recently. By this method, we analysed the correlation between pregnancy outcome, neonatal thyroid stimulating hormone (TSH) level and maternal thyroid diseases.

Methods: A total of 1744 pregnant women participated in the study and 1747 babies were born from those women (three bore twins). The levels of TSH, free thyroxine (FT4) and thyroid peroxidase antibodies (TPO-Ab) of mothers were quantified by electrochemistry immunoassay (ECL). The levels of neonatal blood TSH were detected by time-resolved fluorescence immunoassay (TRFIA). All data were collected and statistically analysed by SPSS 13.0 software.

Results: With our new SLRI method, we found that $0.11 \% \sim 3.84 \%$ pregnant women would get thyroid diseases. Subclinical hypothyroidism was the most common maternal thyroid disorder. Being positive for thyroid peroxidase antibodies was a significant risk factor of subclinical hypothyroidism during pregnancy. The median, P2.5 P97.5, and interquartile range (IQR) of neonatal TSH (N-TSH) of 1747 babies were $2.72 \mathrm{mIU} / \mathrm{L}, 0.10 \sim 8.01 \mathrm{mIU} / \mathrm{L}$ and $2.62 \mathrm{mIU} / \mathrm{L}$, respectively; $28.6 \%$ of pregnant women with thyroid diseases developed pregnancy complications. The prevalence was significantly higher than in the normal thyroid function group $(\mathrm{p}<0.001)$. The levels of N-TSH were low correlated with maternal TSH levels $(\mathrm{p}<0.05)$, but there were no significant correlations between N-TSH and maternal FT4 and maternal $T P O-A b(\mathrm{p}>0.05)$.

Conclusions: Thyroid disorders, especially subclinical hypothyroidism, are common in pregnant women. These disorders are associated with pregnancy and fetal outcome. Routine maternal thyroid function screening is important and should be recommended.
\end{abstract}

Keywords: Neonatal screening, pregnancy, pregnancy outcome, thyroid function

\section{Evaluación Clínica con Intervalos de Referencia Longitudinal Auto-Secuencial: Evolución Clínica del Embarazo y Niveles de la Hormona Estimulante de la Tiroides en Neonatos Asociados con Enfermedades Tiroideas Maternas}

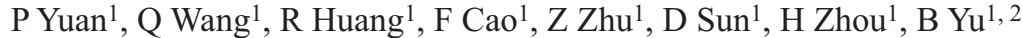

\begin{abstract}
RESUMEN
Objetivo: Intentamos evaluar la función tiroidea materna en un nuevo intervalo de referencia longitudinal auto-secuencial (SLRI) que establecimos recientemente. Por este método, analizamos la correlación entre el resultado del embarazo, el nivel de la hormona estimulante de la tiroides (TSH) en neonatos, y las enfermedades tiroideas maternas

Métodos: Un total de 1744 mujeres embarazadas participó en el estudio y 1747 bebés nacieron de esas mujeres (tres de ellas tuvieron gemelos). Los niveles de TSH, la tiroxina libre (FT4), y los anticuerpos de la peroxidasa tiroidea (TPO-Ab) de las madres, fueron cuantificados mediante inmunoensayo elec-
\end{abstract}

From: ${ }^{1}$ Changzhou Women and Children Health Hospital affiliated to Nanjing Medical University, Changzhou 213003, Jiangsu Province, China and ${ }^{2}$ Jiangsu University, Zhenjiang 212000, Jiangsu Province, China.
Correspondence: Dr B Yu, Changzhou Women and Children Health Hospital, Nanjing Medical University, No 26 Bo Ai Road, Changzhou City 213003, Jiangsu Province, China. E-mail: ybcz0519@163.com 
troquímico (ECL). Los niveles de TSH en la sangre de los neonatos, fueron determinados mediante inmunoensayo por fluorescencia resuelto en el tiempo (TRFIA). Todos los datos fueron recogidos y analizados estadisticamente usando el software SPSS 13.0.

Resultados: Con nuestro nuevo método SLRI, encontramos que $0.11 \% \sim 3.84 \%$ de las mujeres embarazadas contraerán enfermedades tiroideas. El hipotiroidismo subclínico fue el trastorno de la tiroides materna más común. Ser positivo a los anticuerpos de la peroxidasa tiroidea fue un factor de riesgo significativo del hipotiroidismo subclínico durante el embarazo. La mediana, P2.5 P97.5, y el rango intercuartil (IQR) de la TSH (N-TSH) neonatal de los 1747 bebés fueron $2.72 \mathrm{mIU} / \mathrm{L}, 0.10 \sim 8.01 \mathrm{mIU} / \mathrm{L} y$ $2.62 \mathrm{mIU} / \mathrm{L}$ respectivamente. El $28.6 \%$ de las mujeres embarazadas que tenían enfermedades tiroideas, desarrollaron complicaciones del embarazo. La prevalencia fue significativamente más alta que en el grupo con función tiroidea normal $(p<0.001)$. Los niveles de N-TSH fueron bajos en correlación con los niveles de TSH maternos ( $p<0.05$ ), pero no hubo ninguna correlación significativa entre la N-TSH y la FT4 materna, y la TPO-Ab materna ( $\mathrm{p}>0.05)$.

Conclusiones: Los trastornos tiroideos, especialmente el hipotiroidismo, son comunes en las mujeres embarazadas. Estos trastornos se hallan asociados con el resultado del embarazo y el resultado fetal. El tamizaje de rutina de la función tiroidea materna es importante y debe recomendarse.

Palabras claves: Tamizaje neonatal, embarazo, resultado del embarazo, función tiroidea

West Indian Med J 2013; 62 (1): 29

\section{INTRODUCTION}

Thyroid disorders are common endocrine problems in pregnant women and affect maternal and fetal outcome. The increased prevalence of gestation-related thyroid disorders and the importance for both mother and child were reported in multiple studies throughout the world. Subclinical hypothyroidism is one of the most common thyroid dysfunction during pregnancy: $2.3 \%$ of pregnant women will manifest that disorder, accounting for about $92 \%$ of hypothyroidism (1). Maternal hypothyroidism, even very mild, can have adverse effects on both pregnancy outcome and children's development (2). Maternal thyroid dysfunction or only the presence of thyroid-specific antibodies will increase the risk of early abortion, neonatal morbidity $(3,4)$ and some obstetrical complications $(5,6)$, such as premature delivery, gestational hypertension, pre-eclampsia and placental abruption. Accurate evaluation of thyroid function is therefore very important during pregnancy.

In clinic, to evaluate thyroid function during pregnancy, the appropriate reference intervals are crucial. Because of complicated physiological changes during pregnancy, it is vital to establish the normal gestational-specific reference values for thyroid function. If a non-pregnant reference range is used, many maternal thyroid diseases could be potentially misclassified (7-9). In our last study, we established a new selfsequential longitudinal reference interval which was based on the same pregnant women group (10). Compared with other general gestation-specific reference intervals $(9,11-17)$, it could reduce the variation which was caused by sampling error from different groups. Our method could reflect the changes of thyroid function in pregnant women more realistically, and could decrease the percentage of potential misclassification of thyroid dysfunction during pregnancy.
On the other hand, many studies have paid more attention to the relationship between maternal thyroid function and fetal outcome. Most researchers focussed on how maternal thyroid dysfunction affected children's development, such as cognitive functioning (18), neuropsychological development (19) and so on. It is well known that thyroid hormones are important factors for neonatal normal growth, bone development and neural development, particularly within six months after birth. Congenital hypothyroidism $(\mathrm{CH})$ is the most prevalent endocrine disorder in the newborn and affects 1 in 3000-4000 newborn babies (20). Hypothyroidism in the newborn period is easily overlooked without neonatal screening. Delayed diagnosis leads to the most severe outcome of $\mathrm{CH}$. Unrecognized $\mathrm{CH}$ leads to mental retardation (21). We therefore emphasized the importance of neonatal screening in this study and questioned whether maternal thyroid diseases can also affect neonatal thyroid hormones. Recently, Papendieck et al (22) reported that maternal hyperthyroidism implies the risk of thyroid abnormalities in the newborn. Neonates born from women with thyroid dysfunction were prone to get neonatal thyroid disorders. Rovelli et al (23) also found that higher serum thyroid stimulating hormone (TSH) level was frequently observed in infants born to mothers affected by autoimmune thyroiditis. However, it still remains unclear.

We designed this study to evaluate the relationship between pregnancy outcome, neonatal TSH level and maternal thyroid diseases. Using the self-sequential longitudinal reference intervals (SLRI) of thyroid function during pregnancy which we established, we analysed the correlation between pregnancy complication and maternal thyroid diseases. After follow-up of their newborn babies, we detected the neonatal blood TSH level and analysed the relationship between maternal thyroid function and fetal TSH screening. 


\section{SUBJECTS AND METHODS}

This study was designed and undertaken at the Changzhou Women and Children Health Hospital of Nanjing Medical University, Jiangsu Province, China. The cases of this study comprised the pregnant women who regularly checked in to our hospital for early prenatal care from June 2008 to June 2009. The study design and protocol were reviewed and approved by the ethics committee of Changzhou Women and Children Health Hospital affiliated to Nanjing Medical University.

A total of 1744 pregnant women participated in the study, including 458 cases in the $1^{\text {st }}$ trimester, 449 cases in the $2^{\text {nd }}$ trimester, and 837 cases in the $3^{\text {rd }}$ trimester. Their mean age was $27.13 \pm 7.36$ years and the mean height was $156.8 \pm$ $10.4 \mathrm{~cm}$. All cases were followed by a survey of hospital medical record and telephone interview. One thousand seven hundred and forty-seven babies were born from those pregnant women (three bore twins). All babies were included in the neonatal screening system of Changzhou city.

For mothers, $3 \mathrm{ml}$ blood was collected by simple needle aspiration. The samples were centrifuged at $3000 \mathrm{rpm}$ for five minutes to remove cells. The sera were stored at $-86^{\circ} \mathrm{C}$ until assays. For newborn babies, three drops of blood were taken by heel prick after 72 hours of age. After the blood dried up naturally, the blood filter paper was stored at $2 \sim 8{ }^{\circ} \mathrm{C}$.

The levels of serum TSH, free thyroxine (FT4) and thyroid peroxidase antibodies (TPO-Ab) were quantified by electrochemistry immunoassay (ECL) using COBAS e601 automated analyser (Roche Diagnostics, Germany). The detection range of serum TSH is $0.005 \sim 100 \mathrm{mlU} / \mathrm{L}, 0.3 \sim 100 \mathrm{pmol} / \mathrm{L}$ for FT4 and 5 600 IU/ml for TPO-Ab.

The level of neonatal blood TSH was detected by timeresolved fluorescence immunoassay (TRFIA) using VICTOR2 1420 analyser (Perkin-Elmer, USA).

All data were collected and statistically analysed by SPSS 13.0 software. Results of parameters were expressed as median $(\mathrm{M})$, interquartile range (IQR), 2.5 th percentile (P2.5) and $97.5^{\text {th }}$ percentile (P97.5). Correlation analyses were performed using Spearman's rank correlation test. Positive ratios were calculated by $\chi^{2}$-test. Mann-Whitney (U test) was used to compare the difference between the two different groups. A $p$-value of less than 0.05 was considered to be statistically significant.

\section{RESULTS}

In order to evaluate the value of SLRI, we used it to investigate the thyroid function of 1744 pregnant women; 252 women $(14.4 \%)$ at various trimesters whose serum TSH concentration was within SLRI would be misclassified, while 23 women $(1.3 \%)$ with a TSH concentration outside the limit would not be identified. The potential for misclassification of TSH results was greatest in the $1^{\text {st }}$ trimester $(31.0 \%)$.

Using the SLRI to evaluate thyroid function during pregnancy, $0.11 \% \sim 3.84 \%$ pregnant women got thyroid diseases (Table 1), including subclinical hypothyroidism (67/1744, $3.84 \%)$, hypothyroxinaemia $(30 / 1744,1.72 \%)$, subclinical hypothyroxinaemia $(27 / 1744,1.55 \%)$, hypothyroxinaemia (13/1744, 0.75\%), and hypothyroidism (2/1744, 0.11\%). Subclinical hypothyroidism was the most common maternal thyroid disorder. One hundred and fifty-one (8.66\%) pregnant women were TPO-Ab positive throughout the gestation. Furthermore, TPO-Ab was a significant risk factor of subclinical hypothyroidism during pregnancy (OR 4.738, 95\% CI 2.741, 8.187 ). The positive rate of TPO-Ab was $28.4 \%$ in the subclinical hypothyroidism group.

Among the 1744 pregnant women who participated in the study, 346 types of pregnancy complications occurred: anaemia (95/346, 27.5\%), gestational diabetes mellitus (GDM, 72/346, 20.8\%), fetal distress $(47 / 346,13.6 \%)$ and intrahepatic cholestasis of pregnancy (ICP, 44/346, 12.7\%) were the top four.

After drawing blood from a heel prick of the 1747 babies born during the study period, the median concentration, P2.5 P97.5 and IQR of neonatal TSH were $2.72 \mathrm{mIU} / \mathrm{L}$, $0.10 \sim 8.01 \mathrm{mIU} / \mathrm{L}$ and $2.62 \mathrm{mIU} / \mathrm{L}$, respectively. Figure 1 shows blood TSH concentration distribution in the neonatal subjects.

The blood TSH levels of 20 newborn babies were higher than the cut-off level $(>9 \mathrm{mIU} / \mathrm{L})$. We followed up these newborns and checked their serum TSH concentration again (10 21 days after birth). The levels of serum TSH and FT4 of 19 cases were within the normal range. Only one baby's TSH was still higher, but FT4 was normal. At a later follow-up, his TSH was in the normal range at 35 days of age. All 20 newborn babies were therefore considered as transient hypothyroidism. We did not screen out $\mathrm{CH}$ in the study.

Table 1: The prevalence of thyroid disorders during pregnancy; $\mathrm{n}(\%)$

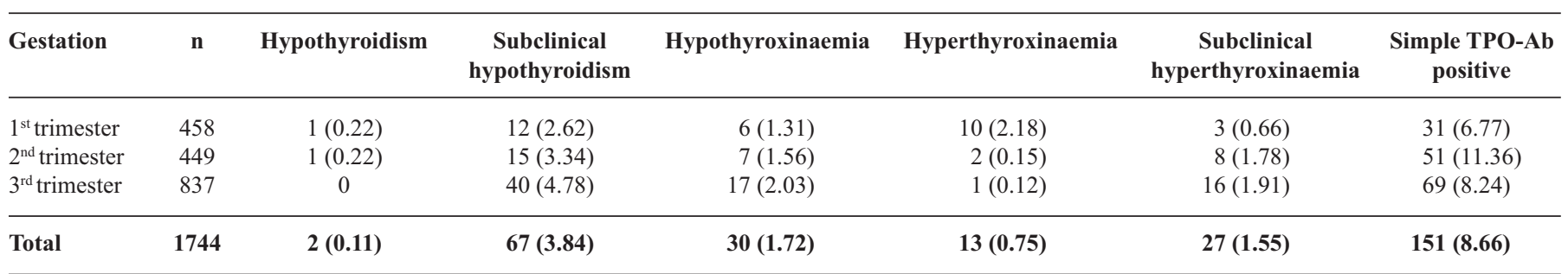

TPO-Ab: thyroid peroxidase antibodies 


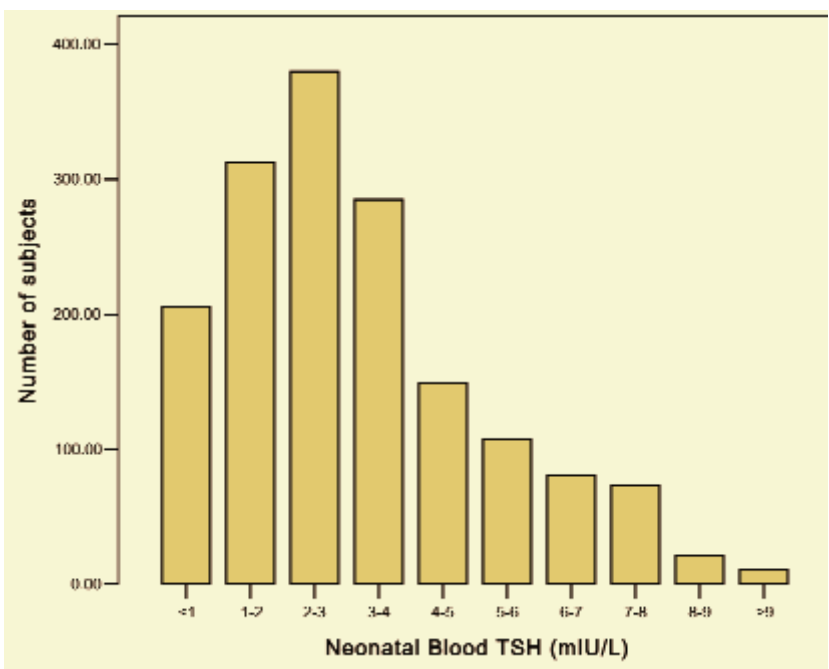

Fig. 1: Blood thyroid stimulating hormone (TSH) concentration distribution in the neonatal subjects.

\section{Maternal thyroid diseases and pregnancy outcome}

During pregnancy, women with thyroid dysfunction had an increased rate of pregnancy complications (Table 2); $28.6 \%$ of the pregnant women with thyroid diseases had any kind of pregnancy complications. The prevalence was significantly higher than in the normal thyroid function group $\left(\chi^{2}=16.8656\right.$, $p<0.001)$. Gestational diabetes mellitus, anaemia and ICP were the most common complications.

Except for hypothyroidism, subclinical hypothyroid patients were more prone to have complications, including anaemia (13.4\%), hypertensive disorders complicating pregnancy (HDCP, 7.46\%), GDM (7.46\%), fetal distress (4.48\%), ICP $(1.49 \%)$ and pre-eclampsia (1.49\%). Moreover, if women were TPO-Ab positive in pregnancy, $25.2 \%$ of cases had pregnancy complications later. The most common was GDM $(7.28 \%)$.
Maternal thyroid hormones and neonatal TSH level

Table 3 and Figs. $2 \mathrm{~A}-\mathrm{C}$ show the correlations between neonatal TSH (N-TSH) level and maternal thyroid hormones. The levels of N-TSH correlated with maternal TSH (M-TSH) levels $(p<0.05)$ [Fig. 2], including $1^{\text {st }}$ trimester $(\mathrm{r}=0.162, p<$ $0.001), 2^{\text {nd }}$ trimester $(\mathrm{r}=0.145, p<0.05)$ and $3^{\text {rd }}$ trimester $(\mathrm{r}=$ $0.171, p<0.001)$. However, there were no significant correlations between N-TSH and maternal FT4 (M-FT4) and maternal TPO-Ab (M-TPO-Ab) $[p>0.05]$. No correlations were found between the parameters of birthweight, Apgar scores in

Table 3: The correlations between neonatal thyroid stimulating hormone (N-TSH) level and maternal thyroid hormone

\begin{tabular}{lcccc}
\hline Gestation & $\mathbf{n}$ & Group & $\mathbf{r}$ & $\boldsymbol{p}$ \\
\hline $1^{\text {st }}$ trimester & 458 & N-TSH and M-TSH & 0.162 & 0.001 \\
& & N-TSH and M-FT4 & 0.094 & 0.055 \\
& & N-TSH and M-TPO-Ab & 0.04 & 0.934 \\
$2^{\text {2d }}$ trimester & 449 & N-TSH and M-TSH & 0.145 & 0.003 \\
& & N-TSH and M-FT4 & 0.041 & 0.396 \\
& & N-TSH and M-TPO-Ab & 0.031 & 0.525 \\
$3^{\text {rd }}$ trimester & \multirow{3}{*}{837} & N-TSH and M-TSH & 0.171 & 0.000 \\
& & N-TSH and M-FT4 & 0.038 & 0.292 \\
& & N-TSH and M-TPO-Ab & 0.093 & 0.009 \\
\hline
\end{tabular}

M-TSH: maternal thyroid stimulating hormone; M-FT4: maternal free thyroxine; M-TPO-Ab: maternal thyroid peroxidase antibodies

neonates and serum concentrations of TSH during pregnancy in their mothers $(p>0.05)$.

Analysis of neonatal blood TSH level between different types of maternal thyroid disorders (Table 4) showed that TSH of the newborn from mothers with subclinical hypothyroidism was higher $(p>0.05)$, while TSH levels of babies whose mothers had hypothyroxinaemia was decreased significantly $(p>$ 0.05). However, there was no significant difference in N-TSH between the groups born from women with other maternal thyroid disorders and normal thyroid function $(p>0.05)$.

Table 2: Relationship between maternal thyroid dysfunction and pregnancy complications; $\mathrm{n}(\%)$

\begin{tabular}{|c|c|c|c|c|c|c|c|c|c|}
\hline Group & $\mathbf{n}$ & Preeclampsia & Premature & HDCP & GDM & Fetal distress & ICP & Anaemia & Total \\
\hline Subclinical hypothyroidism & 67 & $1(1.49)$ & - & $5(7.46)$ & $5(7.46)$ & $3(4.48)$ & $1(1.49)$ & $9(13.4)$ & $24(35.8)$ \\
\hline Hypothyroidism & 2 & - & - & - & - & - & $2(100)$ & - & $2(2 / 2)$ \\
\hline Hypothyroxinaemia & 30 & - & - & $4(13.3)$ & - & - & $2(6.67)$ & $2(6.67)$ & $8(26.7)$ \\
\hline Hyperthyroxinaemia & 13 & - & - & - & $1(7.69)$ & $1(7.69)$ & - & - & $2(15.4)$ \\
\hline $\begin{array}{l}\text { Subclinical } \\
\text { hyperthyroxinaemia }\end{array}$ & 27 & - & $3(11.1)$ & $1(3.70)$ & $3(11.1)$ & $1(3.70)$ & - & $1(3.70)$ & $9(33.3)$ \\
\hline TPO-Ab positive & 151 & $3(1.99)$ & $2(1.32)$ & $3(1.99)$ & $11(7.28)$ & $5(3.31)$ & $10(6.62)$ & $4(2.65)$ & $38(25.2)$ \\
\hline $\begin{array}{l}\text { Total of maternal thyroid } \\
\text { dysfunction }\end{array}$ & 290 & $4(1.38)$ & $5(1.72)$ & $13(4.48)^{*}$ & $20(6.90)^{*}$ & $10(3.45)$ & $15(5.17)^{*}$ & $16(5.52)$ & $83(28.6)^{*}$ \\
\hline Normal thyroid function & 1454 & $21(1.44)$ & $17(1.17)$ & $28(1.93)$ & $52(3.58)$ & $37(2.54)$ & 29 (1.99) & $79(5.43)$ & $263(18.1)$ \\
\hline Total & 1744 & 25 (1.43) & $22(1.26)$ & $41(2.35)$ & $72(4.13)$ & 47 (2.69) & $44(2.52)$ & $95(5.45)$ & $346(19.8)$ \\
\hline
\end{tabular}

* Compared with pregnant women with normal thyroid function, $p<0.05$.

HDCP: hypertensive disorders complicating pregnancy; GDM: gestational diabetes mellitus; ICP: intrahepatic cholestasis of pregnancy; TPO-Ab: thyroid peroxidase antibodies 


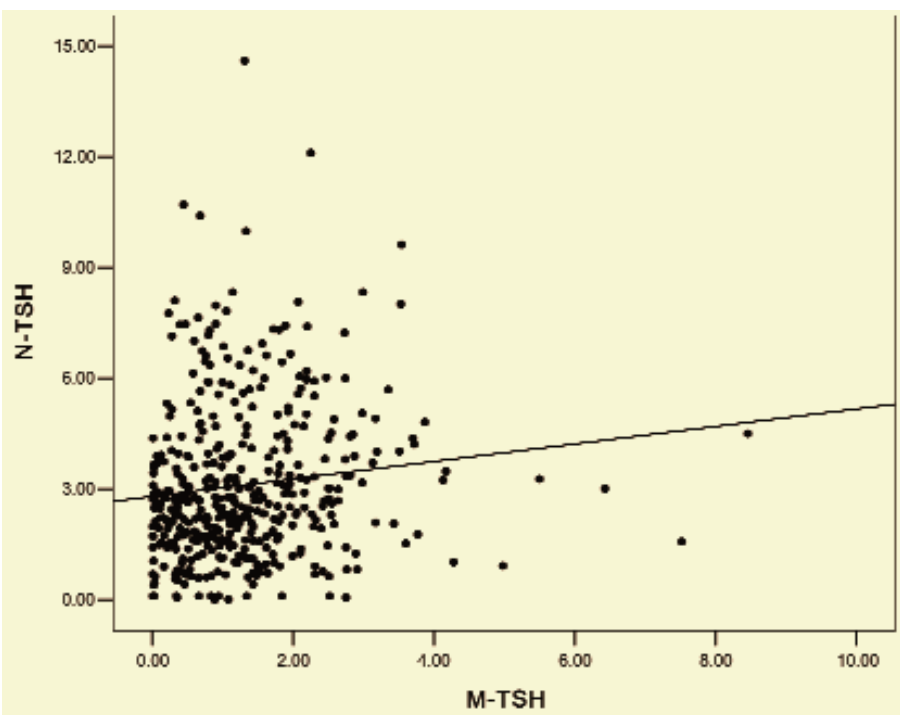

Fig. 2: Relationship between neonatal thyroid stimulating hormone $(\mathrm{N}-$ $\mathrm{TSH}$ ) concentration and maternal thyroid stimulating hormone (MTSH).

A) in $1^{\text {st }}$ trimester $(r=0.162, p<0.001)$.

Table 4: Relationship between maternal thyroid disorders and neonatal thyroid stimulating hormone $(\mathrm{N}-\mathrm{TSH})$ level

\begin{tabular}{lccc}
\hline Group & $\mathbf{n}$ & \multicolumn{2}{c}{ N-TSH (mIU/L) } \\
\cline { 3 - 4 } & & Median (P2.5 P97.5) & IQR \\
\hline $\begin{array}{l}\text { Subclinical hypothyroidism } \\
\text { Hypothyroxinaemia }\end{array}$ & 67 & $3.43(0.97 \sim 6.22)^{*}$ & 1.81 \\
$\begin{array}{l}\text { Subclinical } \\
\text { hyperthyroxinaemia }\end{array}$ & 30 & $2.54(0.78 \sim 8.33)$ & 1.98 \\
$\begin{array}{l}\text { Hyperthyroxinaemia } \\
\text { TPO-Ab positive }\end{array}$ & 13 & $1.73(0.45 \sim 6.22)^{*}$ & 2.62 \\
$\begin{array}{l}\text { Normal thyroid } \\
\text { function }\end{array}$ & 151 & $2.61(0.53 \sim 7.99)$ & 2.56 \\
\hline
\end{tabular}

* Compared with newborn babies from women with normal thyroid function, $p<0.05$.

$\mathrm{TPO}-\mathrm{Ab}$ : thyroid peroxidase antibodies

\section{DISCUSSION}

During pregnancy, maternal thyroid disorders will affect both maternal and fetal outcome. The basic premise for clinical management is in accurate laboratory measurement. When we clinically evaluate the maternal thyroid function, it is advised to use a gestational-specific reference range. If a non-pregnant reference interval is used, 5.6\% 18.3\% maternal thyroid diseases could be potentially misclassified (7-9). However, most gestational-specific reference ranges were based on cross-sectional studies from different women in different stages of gestation. In a previous study (10), we have established a new SLRI which was based on the same group of pregnant women. We found that intra-individual variations of thyroid hormones

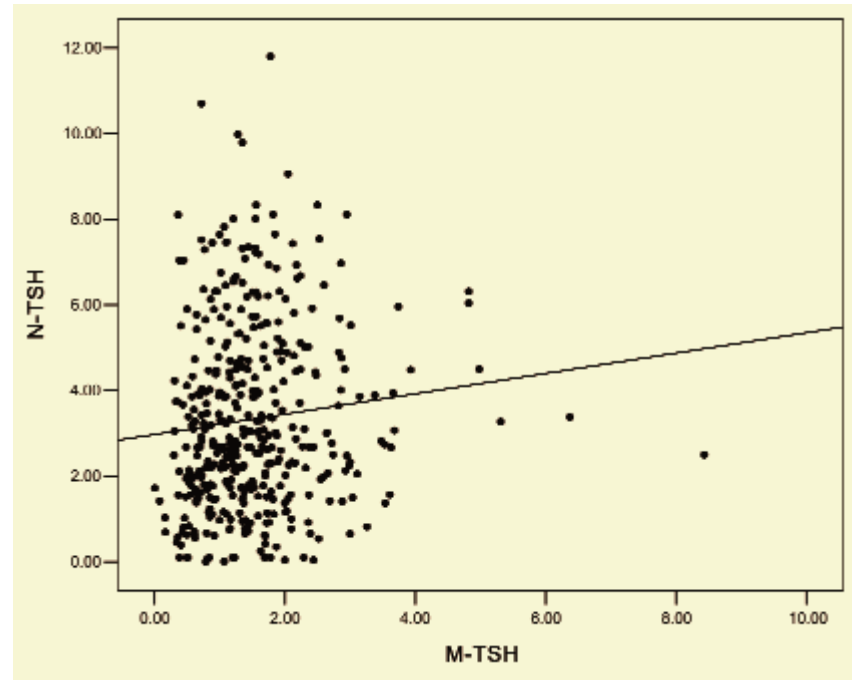

B) in $2^{\text {nd }}$ trimester $(\mathrm{r}=0.145, p<0.05)$.

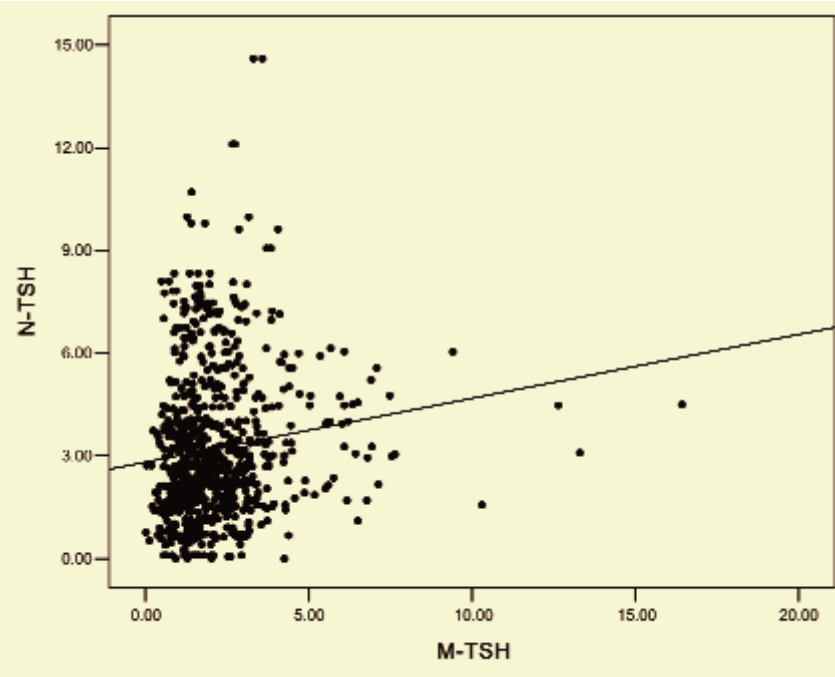

C) in $3^{\text {rd }}$ trimester $(\mathrm{r}=0.171, p<0.001)$.

were smaller than inter-individual variations during pregnancy. Self-sequential longitudinal reference interval could reduce the variation caused by sampling error from different groups and reflect the changes of thyroid function in pregnant women more realistically, resulting in a more important value for clinical diagnosis and therapy. We explored the clinical value of SLRI by first taking TSH as an example. After investigating the status of thyroid hormone by screening 1744 pregnant women with SLRI, we found that if the non-pregnant reference intervals of TSH were used, $6.1 \% \sim 31.0 \%$ of women would be misclassified by thyroid status during pregnancy. Utilization of non-pregnant reference intervals has the potential to result in a large number of misclassified results; SLRI can be used to decrease the percentage of potential misclassification of thyroid dysfunction. 
In this study, $0.11 \% \sim 3.84 \%$ of pregnant women would get any kind of thyroid disease. Thyroid hormone deficiency was the most common maternal thyroid disorder and accounted for about $71.2 \%$ of all thyroid disorders during pregnancy. In that group, $97.98 \%(97 / 99)$ of women were in the subclinical status, and only $2.02 \%(2 / 99)$ of pregnant women with thyroid hormone deficiency would become hypothyroid (serum TSH raised, FT4 or TT4 decreased). These results are consistent with Casey's report $(1,8)$. There are three abnormal situations in subclinical maternal thyroid hormone deficiency: subclinical hypothyroidism (serum TSH raised, FT4 or TT4 are normal), hypothyroxinaemia (serum TSH is normal, FT4 or TT4 decreased) and TPO-Ab positive (serum TSH, FT4 or TT4 are normal). In our study, subclinical hypothyroidism and hypothyroxinaemia occupied the top two of thyroid disorders; their prevalence was $3.84 \%$ and $1.72 \%$, respectively. The primary problem of hypothyroidism during pregnancy is diagnostic criteria. Because of physiological changes in the mother, serum TSH level decreased during the $1^{\text {st }}$ trimester, and then increased gradually which resulted in the difficulties of clinical diagnosis. About one-third of pregnant women with subclinical hypothyroidism $(24,25)$ might be missed by using non-pregnancy criteria. Therefore, it is reasonable and necessary to diagnose thyroid hormone deficiency in pregnant women with gestational-specific reference. Here, we recommend the SLRI which we established, to clinically evaluate maternal thyroid function and our results demonstrated that it can give more accurate value for diagnosis and therapy.

Hypothyroidism is a risk factor for pregnancy and child development $(2,18,26)$. According to our study, subclinical hypothyroidism was the most common thyroid disorder during pregnancy; only $2.02 \%$ of pregnant women with thyroid hormone deficiency would become hypothyroid. Recently, some researchers showed that maternal subclinical hypothyroidism is also associated with pregnancy outcome, and it could result in adverse effects on baby's growth, but there were different opinions $(1,2,18,19,27)$. At the same time, it is a bone of contention whether all pregnant women should be routinely screened and treated for subclinical hypothyroidism $(25,28)$. Our study showed that mothers with subclinical hypothyroidism were prone to have pregnancy complications, including anaemia, HDCP, GDM, fetal distress, ICP, pre-eclampsia etc. The risk of HDCP was significantly higher than in the normal thyroid function group $(p<0.05)$. The TSH of newborn babies whose mothers had subclinical hypothyroidism was higher $(p<0.05)$. It is well known that thyroid hormones are important factors for neonatal normal growth, bone and neural development, particularly within six months after birth. Fu et al found that mothers with hypothyroidism had greater effect on neonatal thyroid function (29). Higher TSH level in newborn babies adversely affects their development. Recently, the relationship between maternal and fetal thyroid function were reported in a few studies throughout the world $(22,23)$. In the present study, we found that N-TSH was low correlated with mother's TSH. However, the clinical sig- nificance of this is questionable since the number $(\mathrm{r}<0.2)$ is so small. There were one or two neonates with high TSH born from high TSH mothers. Therefore, it was difficult to conclude that high TSH mothers generate high TSH neonates. All 20 newborn babies whose TSH was higher than the cut-off value had transient hypothyroidism. All suspected infants should be treated as having $\mathrm{CH}$ for the first three years of life, due to the risks of mental retardation (30). We will follow-up these babies and check serum TSH if the occasion should arise. There is no consensus on screening for thyroid function in pregnancy. But based on our results, we emphasize the importance of routine antenatal subclinical hypothyroidism screening. It is useful to both mothers and children.

Thyroid peroxidase (TPO) is one of the major enzymes in thyroid hormone synthesis. It can mediate the occurrence of autoimmune thyroid disease (31). Higher TPO-Ab level during pregnancy is also a marker for the development of post partum thyroiditis (32); about $50 \%$ of TPO-Ab positive women will get thyroid dysfunction after delivery (33). Some reports showed that mothers who are TPO-Ab positive are also at risk for pregnancy complication and poor fetal outcome $(34,35)$. In the present study, $8.66 \%$ of pregnant women were TPO-Ab positive throughout the gestation. Furthermore, the positive rate of TPO-Ab was $28.4 \%$ in the subclinical hypothyroidism group which was higher than the other group. Compared with the control group, women who were TPO-Ab positive were prone to have any kind of pregnancy complication. If women were TPO-Ab positive in pregnancy, $25.2 \%$ of cases would have pregnancy complications later. However, there were no significant correlations between N-TSH and maternal TPO-Ab $(p>0.05)$. Overall, we think screening for TPO-Ab in pregnant women is also recommended and important, especially to mothers.

In summary, we used a new criteria which we established to evaluate maternal thyroid diseases, analysed the relationship between pregnancy outcome, neonatal TSH level and maternal thyroid diseases. Based on our results, we found that thyroid disorders, especially subclinical hypothyroidism, are common in pregnant women. It is a risk factor for pregnancy complications and can affect the level of neonatal blood TSH. We therefore recommend routine maternal thyroid function screening for both mothers and newborns.

\section{ACKNOWLEDGEMENTS}

We thank all the study participants for their contributions. The authors declare that they have no competing interests. This study was supported by grants from Changzhou Health Bureau and Key Laboratory of Changzhou City.

\section{REFERENCES}

1. Casey BM, Dashe JS, Wells CE, McIntire DD, Byrd W, Leveno KJ et al. Subclinical hypothyroidism and pregnancy outcomes. Obstet Gynecol 2005; 105: 239-45.

2. Alexander EK. Thyroid function: the complexity of maternal hypothyroidism during pregnancy. Nat Rev Endocrinol 2009; 5: 480-1. 
3. Gärtner R. Thyroid diseases in pregnancy. Curr Opin Obstet Gynecol 2009; 21: 501-7.

4. Idris I, Srinivasan R, Simm A, Page RC. Maternal hypothyroidism in early and late gestation: effects on neonatal and obstetric outcome. Clin Endocrinol 2005; 63: 560-5.

5. Galofre JC, Davies TF. Autoimmune thyroid disease in pregnancy: a review. J Womens Health 2009; 18: 1847-56.

6. Luton D, Le Gac I, Noel M, Guibourdenche J, Polak M. Thyroid function during pregnancy in women with past Graves disease. BJOG 2005, 112: $1565-7$.

7. Stricker R, Echenard M, Eberhart R, Chevailler MC, Perez V, Quinn FA et al. Evaluation of maternal thyroid function during pregnancy: the importance of using gestational age-specific reference intervals. Eur J Endocrinol 2007; 157: 509-14.

8. Shan ZY, Chen YY, Teng WP, Yu XH, Li CY, Zhou WW et al. A study for maternal thyroid hormone deficiency during the first half of pregnancy in China. Eur J Clin Invest 2009; 39: 37-42.

9. Thevarajah M, Chew YY, Lim SC, Sabir N, Sickan J. Determination of trimester specific reference intervals for thyroid hormones during pregnancy in Malaysian women. Malays J Pathol 2009; 31: 23-7

10. Yu B, Wang QW, Huang RP, Cao F, Zhu ZQ, Sun DC et al. Establishment of a self-sequential longitudinal reference intervals of maternal thyroid function during pregnancy. Exp Biol Med 2010; 235: 1212-15. DOI: 10.1258/ebm.2010.010136.

11. Yan Y, Dong Z, Dong L et al. Trimester-specific reference data of thyroid hormones for normal pregnancy. Chin J Endocrinol Metab 2008; 24: 60912 .

12. Li J, Teng W-P, Shan Z-Y, Li C-Y, Zhou W-W, Gao B et al. Gestational month-specific reference ranges for TSH and thyroxine in Han nationality women in iodine sufficient area of China. Chin J Endocrinol Metab 2008; 24: 605-8.

13. Bocos-Terraz JP, Izquierdo-Alvarez S, Bancalero-Flores JL, AlvarezLahuerta R, Aznar-Sauca A, Real-López E et al. Thyroid hormones according to gestational age in pregnant Spanish women. BMC Res Notes 2009; 26: 237-46

14. Marwaha RK, Chopra S, Gopalakrishnan S, Sharma B, Kanwar RS, Sastry A et al. Establishment of reference range for thyroid hormones in normal pregnant Indian women. BJOG 2008; 115: 602-6.

15. Gilbert RM, Hadlow NC, Walsh JP, Fletcher SJ, Brown SJ, Stuckey BG et al. Assessment of thyroid function during pregnancy: first-trimester (weeks 9-13) reference intervals derived from Western Australian women. Med J Aust 2008; 189: 250-3.

16. Cotzias C, Wong SJ, Taylor E, Seed P, Girling J. A study to establish gestation-specific reference intervals for thyroid function tests in normal singleton pregnancy. Eur J Obstet Gynecol Reprod Biol 2008; 137: 61-6.

17. Springer D, Zima T, Limanova Z. Reference intervals in evaluation of maternal thyroid function during the first trimester of pregnancy. Eur $J$ Endocrinol 2009; 160: 791-7.

18. Henrichs J, Bongers-Schokking JJ, Schenk JJ, Ghassabian A, Schmidt $\mathrm{HG}$, Visser TJ et al. Maternal thyroid function during early pregnancy and cognitive functioning in early childhood: the generation R study. J Clin Endocrinol Metab 2010; 95: 4227-34. Epub 2010 Jun 9.

19. Li Y, Shan Z, Teng W, Yu X, Li Y, Fan C et al. Abnormalities of maternal thyroid function during pregnancy affect neuropsychological development of their children at 25-30 months. Clin Endocrinol (Oxf) 2010; 72: $825-9$.
20. Grüters A, Biebermann H, Krude H. Neonatal thyroid disorders. Horm Res 2003; 59: 24-9.

21. American Academy of Pediatrics, Rose SR; Section on Endocrinology and Committee on Genetics, Foley T, Kaplowitz PB, et al. Update of newborn screening and therapy for congenital hypothyroidism. Pediatrics 2006; 117: 2290-303.

22. Papendieck P, Chiesa A, Prieto L, Gruñeiro-Papendieck L. Thyroid disorders of neonates born to mothers with Graves' disease. J Pediatr Endocrinol Metab 2009; 22: 547-53.

23. Rovelli R, Vigone MC, Giovanettoni C, Passoni A, Maina L, Corrias A. Newborn of mothers affected by autoimmune thyroiditis: the importance of thyroid function monitoring in the first months of life. Ital J Pediatr 2010; 10: 24

24. Dashe JS, Casey BM, Wells CE, McIntire DD, Byrd EW, Leveno KJ et a1. Thyroid-stimulating hormone in singleton and twin pregnancy: importance of gestational age-specific reference ranges. Obstet Gynecol 2005; 106: 753-7.

25. Abalovich M, Amino N, Barbour LA, Cobin RH, De Groot LJ, Glinoer $\mathrm{D}$ et al. Management of thyroid dysfunction during pregnancy and postpartum: an Endocrine Society Clinical Practice Guideline. J Clin Endocnnol Metab 2007; 92 (Suppl 8): S1-S47.

26. Hollowell JG, LaFranchi S, Smallridge RC, Spong CY, Haddow JE, Boyle CA. 2004 where do we go from here? Summary of working group discussions on thyroid function and gestational outcomes. Thyroid 2005; 15: $72-6$.

27. Wikner BN, Sparre LS, Stiller CO, Källén B, Asker C. Maternal use of thyroid hormones in pregnancy and neonatal outcome. Acta Obstet Gynecol Scand 2008; 87: 617-27.

28. Sahu MT, Das V, Mittal S, Agarwal A, Sahu M. Overt and subclinical thyroid dysfunction among Indian pregnant women and its effect on maternal and fetal outcome. Arch Gynecol Obstet 2010; 281: 215-20.

29. Fu J, Jiang Y, Liang L, Zhu H. Risk factors of primary thyroid dysfunction in early infants born to mothers with autoimmune thyroid disease. Acta Pediatr 2005; 94: 1043-8.

30. Büyükgebiz A. Newborn screening for congenital hypothyroidism. J Pediatr Endocrinol Metab 2006; 19: 1291-8.

31. Gangemi S, Saitta S, Lombardo G, Patafi M, Benvenga S. Serum thyroid autoantibodies in patients with idiopathic either acute or chronic urticaria. J Endocrinol Invest 2009; 32: 107-10.

32. Nicholson WK, Robinson KA, Smallridge RC, Ladenson PW, Powe NR. Prevalence of postpartum thyroid dysfunction: a quantitative review. Thyroid 2006; 16: 573-82.

33. Premawardhana LD, Parkes AB, John R, Harris B, Lazarus JH. Thyroid peroxidase antibodies in early pregnancy: utility for prediction of post partum thyroid dysfunction and implications for screening. Thyroid 2004; 14: $610-5$.

34. Männistö T, Vääräsmäki M, Pouta A, Harris B, Lazarus JH. Thyroid dysfunction and autoantibodies during pregnancy as predictive factors of pregnancy complications and maternal morbidity in later life. J Clin Endocrinol Metab 2010; 95: 1084-94.

35. Männistö T, Vääräsmäki M, Pouta A, Hartikainen AL, Ruokonen A, Surcel HM et al. Perinatal outcome of children born to mothers with thyroid dysfunction or antibodies: a prospective population-based cohort study. J Clin Endocrinol Metab 2009; 94: 772-9. 